\title{
Lack of an inhibitory influence of oocytes upon luteinization of porcine granulosa cells in culture
}

\author{
Cornelia P. Channing and A. Tsafriri* \\ Department of Physiology, University of Maryland, School of Medicine, 660 West Redwood Street, \\ Baltimore, Maryland 21201, U.S.A.
}

Nalbandov (1972) suggested that the ovum produces a "luteostatic" substance which prevents luteinization of granulosa cells. This suggestion was derived from three lines of observation: (1) surgical ovectomy in vivo induced luteinization and increased the output of progesterone into the ovarian venous blood of rabbits (El-Fouly, Cook, Nekola \& Nalbandov, 1970) and pigs (Nalbandov, 1972); (2) rat granulosa cell monolayers cultured with only a few oocytes luteinized, whereas those cultured in the presence of many ova retained their granulosa cell morphology (Nekola \& Nalbandov, 1971); and (3) oocytic degeneration on the 3rd day of culture of rat follicles coincided with morphological luteinization of the mural granulosa (Stoklosowa \& Nalbandov, 1972).

To test this hypothesis porcine granulosa cells were cultured with and without the addition of cumulus-enclosed porcine oocytes. Granulosa cells and oocytes were collected from medium and large follicles (3-12 mm) of pig ovaries removed at a local slaughterhouse. Within 20-30 min after death the ovaries were excised and placed in $0.9 \%(\mathrm{w} / \mathrm{v}) \mathrm{NaCl}$ containing $100 \mathrm{i}$.u. penicillin $/ \mathrm{ml}$, and $100 \mu \mathrm{g}$ streptomycin/ml and kept at room temperature until culture 3-5 h later. Details of granulosa cell and oocyte collection have been described elsewhere (Channing \& Ledwitz-Rigby, 1975; Tsafriri \& Channing, 1975a, b). About $1 \times 10^{6}$ granulosa cells were placed in compartments of Multiwell Tissue Culture plates (Falcon, Oxnard, California) containing glass coverslips and grown in $0.5 \mathrm{ml}$ medium 199 with Earle's salts and 25 mM-Hepes buffer (Grand Island Biological Co., New York) supplemented with $15 \%$ pig serum (GIBCO), $1 \mathrm{~mm}$-L-glutamine (GIBCO), 0.03 mM-sodium pyruvate (Eastman Organic Chemicals, Rochester, New York), 2.5 mm-sodium lactate (Sigma Chemical Co., St. Louis, Missouri), $5 \mu \mathrm{g}$ crystalline bovine zinc insulin (Lilly Laboratories, Indianapolis, Indiana)/ $\mathrm{ml}$, and $50 \mu \mathrm{g}$ Gentamicin (Schering Diagnostics, Port Reading, New Jersey)/ml. The pig serum used had an LH activity (in terms of NIH-oLH-S1 units) of $<2 \mathrm{ng} / \mathrm{ml}$ as assayed by a radioligand displacement assay (Channing, 1974). The serum contained $66 \mathrm{pg}$ total oestrogens/ml as measured by radioimmunoassay (Channing \& Coudert, 1976). The progesterone content of the serum was $3 \cdot 8-4 \cdot 1 \mathrm{ng} /$ $\mathrm{ml}$, using a modification (Channing \& Coudert, 1976) of the radioimmunoassay developed by Thorneycroft \& Stone (1970). Morphological luteinization and the number of cells in the cultures were assessed as described elsewhere (Channing, 1970a, b). To some of the cultures cumulusenclosed oocytes (50/culture) and/or ovine LH (NIH-LH-S19;5 $\mathrm{gg} / \mathrm{ml}$ ) were added. Each treatment combination was tested in eight replicate cultures. At 12-h intervals the medium was changed and progesterone was determined by radioimmunoassay using an antiserum against $11 \alpha$-hydroxyprogesterone-BSA conjugate.

The progesterone secretion rate by granulosa cell cultures with and without oocytes and $\mathrm{LH}$ during the $12 \mathrm{~h}$ intervals is presented in Table 1 . To ascertain the effect of oocyte presence and of $\mathrm{LH}$ addition on the progesterone secretion rate by the cultures, two-way analysis of variance (Sokal \& Rohlf, 1969) was performed. LH increased the rate of progesterone accumulation $(P<0.001)$ measured at $12,36,48,60$ and $72 \mathrm{~h}$, whether or not oocytes were present. The presence of oocytes (within their cumuli) caused an unexpected increase rather than a decrease in the rate of progesterone secretion, and morphological luteinization of the granulosa cells was not prevented. Progesterone secretion was increased significantly at $48,60,72$ and $96 \mathrm{~h}$. The increase in progesterone accumulation in oocyterich cultures may have been due to synthesis by the cumulus cells, since rabbit cumulus cells have been shown to luteinize and secrete progesterone in culture (Nicosia \& Mikhail, 1975). The present results

\footnotetext{
* Present address: Department of Hormone Research, The Weizmann Institute of Science, Rehovot, Israel.
} 
Table 1. Effect (mean \pm S.E.M.) of cumulus-enciosed oocytes (50/culture) and $\mathrm{LH}(5 \mu \mathrm{g} / \mathrm{ml})$ on progesterone secretion ( $\mathrm{pg} / \mathrm{cell} /$ day) by porcine granulosa cell cultures

\begin{tabular}{|c|c|c|c|c|c|c|}
\hline \multirow{2}{*}{$\begin{array}{l}\text { Time } \\
\text { (h) }\end{array}$} & \multicolumn{3}{|c|}{ Controls } & \multicolumn{3}{|c|}{ LH } \\
\hline & -Oocytes & +Oocytes & $P$ & -Oocytes & +Oocytes & $P$ \\
\hline 12 & $73 \cdot 0 \pm$ & $89.0 \pm 11.0$ & N.S. & $50 \cdot 5 \pm$ & $110.0 \pm$ & $<0.001$ \\
\hline 24 & $83.0 \pm$ & $102.0 \pm \quad 7.0$ & $<0.05$ & $110.0 \pm \quad 4.0$ & $75.0 \pm$ & $<0.001$ \\
\hline 36 & $168.0 \pm 15.0$ & $143.0 \pm 22.0$ & N.S. & $110.5 \pm 14.0$ & $199.5 \pm 16.0$ & $<0.001$ \\
\hline 48 & $703.0 \pm 111.0$ & $924.0 \pm 86.0$ & $<0.01$ & $486.5 \pm 45.0$ & $1140.0 \pm 70.0$ & $<0.001$ \\
\hline 60 & $1168.0 \pm 100 \cdot 7$ & $2593.0 \pm 967.0$ & $<0.001$ & $1044.0 \pm 56.0$ & $1479.5 \pm 117.0$ & $<0.001$ \\
\hline 72 & $639.0 \pm 104.0$ & $1050.0 \pm 89.0$ & $<0.001$ & $578.0 \pm 69.0$ & $1105.0 \pm 102.0$ & $<0.001$ \\
\hline 84 & $593.0 \pm 101.0$ & $671.0 \pm 116.0$ & N.S. & $543.5 \pm 117.0$ & $120.5 \pm 95.0$ & N.S. \\
\hline 96 & $374.0 \pm 61 \cdot 0$ & $672.0 \pm 96.0$ & $<0.01$ & $439.0 \pm 90.0$ & $581.0 \pm 87.0$ & N.S. \\
\hline 108 & $197.0 \pm 35.0$ & $184.5 \pm 41.0$ & N.S. & $155.5 \pm 39.0$ & $226.0 \pm 34.0$ & N.S. \\
\hline 120 & $143.0 \pm 31.0$ & $148.0 \pm 30.0$ & N.S. & $85.5 \pm 28.0$ & $205 \cdot 0 \pm 23.0$ & $<0.01$ \\
\hline
\end{tabular}

do not support the view that oocytes from medium- and large-sized follicles exert a luteostatic influence on the surrounding granulosa cells. Under these culture conditions the oocytes stay viable and mature to the first polar body within $48 \mathrm{~h}$ (Tsafriri \& Channing, 1975a, b).

Further support for lack of oocyte secretion of a luteinization inhibitor was obtained by Lindner et al. (1974) who observed that ovectomy of explanted rat follicles did not result in an increase of progesterone accumulation in the presence or absence of LH. Nicosia (1972) failed to observe any inhibitory influence of oocytes upon morphological luteinization or progesterone secretion by rabbit granulosa cells. The spontaneous luteinization observed in cultures of preovulatory granulosa cells obtained from equine (Channing, 1969), monkey (Channing, 1970a), porcine (Channing, 1970b), rabbit (Nicosia, 1972) and rat (Fischer \& Kahn, 1972) follicles must therefore be explained by a mechanism other than removal of the egg from the granulosa cells. Ledwitz-Rigby et al. (1977) have observed that addition of follicular fluid obtained from small- and medium-sized follicles can inhibit spontaneous luteinization of porcine granulosa cells. It is therefore likely that there is a luteinization inhibitor present in follicular fluid which originates from somewhere in the ovary other than the oocyte.

We thank Mrs B. Engel and Mrs A. Tsafriri for assistance, and Dr B. Caldwell, Yale University, and Dr G. Niswender, Colorado State University, for a generous supply of oestrogen and progesterone antisera. This study was supported by the Population Council of New York (M76.17) and by the National Institute of Child Health and Human Development (HD 08834), USPHS.

\section{References}

Channing, C.P. (1969) Studies on tissue culture of equine ovarian cell types: culture methods and morphology. J. Endocr. 43, 381-390.

Channing, C.P. (1970a) Effects of the stage of the menstrual cycle and gonadotrophins on luteinization of monkey cells in culture. Endocrinology 87, 49-60.

Channing, C.P. (1970b) Effects of stage of the estrous cycle and gonadotropins upon luteinization of porcine granulosa cells in culture. Endocrinology 87, 156-164.

Channing, C.P. (1974) The use of granulosa cell cultures and suspensions as an assay system for measuring LH and CG. In Gonadotropins and Gonadal Function, pp. 185-198. Ed. N. R. Mougdal. Academic Press, New York.
Channing, C.P. \& Coudert, S.P. (1976) The role of granulosa cells and follicular fluid in estrogen secretion by the monkey ovary in vivo. Endocrinology 98, 568-575.

Channing, C.P. \& Ledwitz-Rigby, F. (1975) Methods for assessing hormone mediated differentiation of ovarian cells in culture and in short-term incubations. In Methods in Enzymology, Vol. 39, Part D, pp. 183-230. Eds J. G. Hardman \& B. W. O'Malley. Academic Press, New York.

Fischer, T.V. \& KAHN, R.H. (1972) Histochemical studies of rat ovarian follicular cells in vitro. In Vitro 7, 201-205.

El-Fouly, M., Cook, B., Nekola, M. \& Nalbandov, A.V. (1970) Role of the ovum in follicular luteiniza, tion. Endocrinology 87, 288-293. 
LeDWITZ-RigBY, F., Rroby, B., GAY, V.L., Young, J., Stetson, M. \& Channing, C.P. (1977) Inhibitory action of porcine follicular fluid upon granulosa cell luteinization in vitro : assay and influence of follicular maturation. J. Endocr. (in press).

LiNDNRR, H.R., TSAFRIRI, A., LIEbERMAN, M.E., ZOR, U., Косн, Y., BAUminger, S. \& BARNEA, A. (1974) Gonadotropin action on cultured Graafian follicles: induction of maturation division of the mammalian oocyte and differentiation of the luteal cell. Recent Prog. Horm. Res. 30, 79-138.

NALBANDOV, A.V. (1972) Interaction between oocytes and follicular cells. In Oogenesis, pp. 513-522. Eds J. D. Biggers \& A. W. Schuetz. University Park Press, Baltimore.

Nekol,a, M.V. \& Nalbandov, A.V. (1971) Morphological changes of rat follicular cells as influenced by oocytes. Biol. Reprod. 1, 154-160.

NicosiA, S.V. (1972) Luteinization of rabbit preovulatory granulosa cells cultured in vitro in presence of follicular oocytes. I. Growth characteristics and progestin biosynthesis. Fert. Steril. 23, 791-801.
Nicosia, S.V. \& Mirhail, G. (1975) Cumuli oophori in tissue culture: hormone production, ultrastructure, and morphometry of early luteninization. Fert. Steril. 26, 427-448.

SoKal, R.R. \& RoHLF, F.J. (1969). Biometry. Freeman and Co., San Francisco.

Stoklosowa, S. \& NAlbandov, A.V. (1972) Luteinization and steroidogenic activity of rat ovarian follicles cultured in vitro. Endocrinology 91, 25-32.

THORNEYCROFT, J.H. \& STONE, S.C. (1972) Radioimmunoassay of serum progesterone in women receiving oral contraceptive steroids. Contraception 5, 129-137.

TSafriri, A. \& Channing, C.P. (1975a) An inhibitory influence of granulosa cells and follicular fluid upon porcine oocyte meiosis in vitro. Endocrinology 96, 922-927.

TSafriri, A. \& Channing, C.P. (1975b) Influence of follicular maturation and culture conditions upon porcine oocyte meiosis in vitro. J. Reprod. Fert. 43, 149-152. 